\title{
RHETORICAL ANALYSIS OF STAND-UP COMEDY PERFORMANCES BY THREE FAMOUS AMERICAN COMICS
}

\author{
Fadly Dzil Ikram \\ Universitas Bengkulu \\ Fadly24DI@gmail.com \\ Safnil Arsyad \\ Universitas Bengkulu \\ safnilarsyad@gmail.com \\ Gita Mutiara Hati \\ Universitas Bengkulu \\ gitamutiara@unib.ac.id
}

\begin{abstract}
ABSTRAK
Penelitian ini bertujuan untuk menemukan retorika di bagian narasi berdasarkan model dari Labov dan teknik stand-up comedy yang paling dominan digunakan oleh Jim Jefferies, Ricky Gervais, dan Bill Burr di penampilan mereka. Ceklis observasi digunakan di penelitian ini. Lima belas topic penampilan yang berbeda dari setiap penampil stand-up comedy dianalisa dengan menggunakan metode deskripsi, menggunakan kuantitaif juga kualitatif. Dari hasil ditemukan bahwa ketiga stand-up comedy menggunakan bagian narasi yang disarankan Labov. Bagian narasi itu adalah abstrack, orientasi, perumitan masalah, dan koda. Juga, teknik yang paling sering digunakan oleh ketiga stand-up comedy adalah rule of three dan one liner. Teknik ini adalah teknik yang paling efektif yang dapat mengundang tawa penonton. Hasil terakhir dari penelitian ini, ada dua pola umum yang dihasilkan oleh ketiga stand-up comedy berdasarkan model Labov tentang bagian narasi.
\end{abstract}

Kata Kunci : Retorika, stand-up comedy, model narasi, teknik stand-up comedy, pola umum

\begin{abstract}
This research aimed at finding the rhetorical of narrative section based on Labov's model and the stand-up comedy techniques which dominantly used by Jim Jefferies, Ricky Gervais, and Bill Burr on their performances. The observation checklist was used in this research. Fifteen different topics performance from each stand-up comedian were analyzed by using descriptive method, using quantitative as well as qualitative data. From the result it was found that three stand-up comedians used narrative section suggested by Labov. The narrative section is abstract, orientation, complicating actions, resolution, and coda. Also, the most frequent techniques used by three stand-up comedians are rule of three and one liner technique. Those techniques are the most effective technique that can trigger audience
\end{abstract}


laughter. The last finding of this research, there are two common patterns created by three stand-up comedians based on Labov's model of narrative sections.

Key Words : Rhetoric, stand-up comedy, narrative model, stand-up comedy techniques, common pattern

\section{INTRODUCTION}

Humor brings two kinds of benefit for people, psychologically and socially. According to Melinda (2010), psychologically, humor helps people to stay emotionally healthy because it has power of changing moods by taking out of depression. Socially, humor strengthens relationship by triggering positive feelings because when people share humor, a positive bond is created (Ziv, 1986:176).

One of humor perfomance is stand up comedy. According to Attardo (2001:62), stand up comedy is a highly artificial, scripted genre perfromance which a single comedian start a performance in front of audiences. Stand-up comedy can be described as a humorous monologue (although the comedian usually starts his show with an attempt to engage the audience in a dialogue), presented to an audience in seemingly spontaneous and conversational manner (Misje, 2002:87). The performer is commonly known as a comic, stand-up comic or comic. In a stand up comedy, the comedian usually recite a grouping of humorous stories, jokes and monologue. The performer is not about simply convincing an audience that you are funny, although that is neccessary; it is also teaching the audience that there is a different way to think about it. (Sankey, 1998). It means comic should be able to convince and persuade the audience to laugh within his jokes. Dealing with convincing audience, it inlines with the idea of rhetoric.

There are three comics that become the object of this research. They are Jim Jefferies, Ricky Gervais and Bill Burr known as famous stand up comedian. First is Jim Jefferies, known as comic from Sydney, Australia and then he moved to America. He is known as the good comic with his Australian accent and sarcastic style proved to be major hit in America. Jefferies is also known as most famous stand up comedy in 2016. Jefferies has performed at numerous festivals, including the Edinburgh Festival Fringe, Just for Laughs Festival and Melbourne International Comedy Festival. He has also appeared on various British and US TV panel shows and radio programs. In 2016, he has his own US Comedy Central program, The Jim Jefferies Show. His stand up comedy performances are already filmed and become famous. One of his successful films is Freedumb in 2016. This film contains of many sarcastics jokes that related to people's life, the way he told his joke is really inviting audience to get laugh.

Second is Ricky Gervais. He is a british comedian and a television producer. Gervais is known as the most influential British comedian. He began his stand-up career in the late 1990s. Gervais also won many awards, for example British Comedy Award, Emmy Award and Golden Globe Award. He already did many stand-up comedy performances and also filmed. One of the most successful stand-up comedy is Out of England that brought jokes that happen in society for example obesity, fund raising, nazis and more.

Third is Bill Burr. He is an American comic, actor, and writer. He has released six stand-up specials. In 2017, Rolling Stone ranked him $17^{\text {th }}$ on its list of the 50 best comics all of time. His style in stand-up is an elaborate act that fuses words and physical reactions together to create humor. Burr is 
known as an aggresive comic that is not affraid to enter topics that are uncomfortable to bring up in ordinary conversation. However, it is with these topics that he has talent to defuse the discomfort with humor with type of comedy that surprise the audience with physical impersonation. Through his tone, volume, and facial expression that seem ridiculous to hear are the source of his talent to capture the audience to laugh with him.

Stand-up comedy is kind of monologue that perform humor. Humor is one of language art, that is would become a narration. It shows about humor that made from narration. Good comic is someone who has ability to create a good narration and successfully deliver the humor itself. Jim Jefferies, Ricky Gervais, and Bill Burr have an ability to persuade audience's laughter with their jokes. The researcher would like to analyse their narrative sections on creating story, by using Labov's model that look narrative section in stand-up comedy performance.

In America stand-up comedy, the comics usually created a story on their performance, therefore they need to create a good narration and deliver it in front of the audiences. They often combine story of their joke with stand-up comedy techniques in order to enhance their performance and trigger audience laughter. The idea on creating narration on stand-up comedy will be in line with Labov's narrative theory which is on his theory the good narration should have five elements of narrative section.

On the education point of view, this research will be useful for the teacher. The good teacher is someone who can make their student put an attention with teacher explanation. One of method is through the comedy itself, by putting the essence of comedy in classroom activity, it will make students attract with teacher explanation. This research will help teacher to create a good narrative of humor.
There are three previous studies relating to this research. First, the research from Muhammad (2017) was talking about the stand-up comedy techniques that is commonly used by stand-up comedian Indo PKU Pekanbaru. It showed the most frequent techniques are rule of three, one liner, roasting technique for triggering audience laughter. The second research from Rutter (2001), talking about rhetoric in stand-up comedy, on how the stand-up comedians in america perform in front of the audiences. The research concern on the ways which successful comedian use rhetorical techniques in comic to develop their joke. He identifies four techniques in stand-up comedy.

The first and the second previous studies found the techniques that used by stand up comedians but in different type of analysis. The second previous study classified the stand-up comedy techniques in four different types, meanwhile the first previous study in eleven types. The third previous study from Ishara (2016), it was talking about rhetorical structure of the debater in order to create a narrative on convincing the adjudicator. The researcher used the theory from Labov, and analyse the narrative section that used by eight debaters. The correlation between the third previous study and this research is both of discourses are spoken discourse. Also, both of elements should convince the audience.

Stand-up comedy is one of language art that has same generic feature of narrative. Generic feature of narrative text is a model that developed by Labov (1972), consist of Abstract, Orientation, Complication, Resolution, and Coda. This model will be useful in order to analyse whether they have a complete narrative sections or not in every performance and also to examine Labov's model in delivering the jokes and strories. On delivering the stories, there are several techniques that commonly used in stand up comedy performance, they are rule of three, 
one liner, impersonation, roasting, comparison, simile, observation, and callback. These technique will be useful in order to trigger audiences' laugher.

The researcher sees Jim Jefferies, Ricky Gervais, and Bill Burr as famous comedians in America. They have a different background, and could be different way to create humor. The researcher would like to analyse the narrative sections from Jim Jefferies, Ricky Gervais, and Bill Burr by using the theory developed by Labov (1972). In the other hand, the researcher would like to see the techniques used by all of them, also to find the most frequent techniques used by these three comics. Last objective of this research, it would like to find the common pattern used by all of three comics based on Labov narrative's model. The researcher would find the common pattern used by all of three comic in order to create a narrative on their story.

\section{METHOD}

This research was constructed as a descriptive qualitative and quantitaive (mix method) study. The descriptive study was appropriated to expose facts related to the problem which is going to be discussed. According to Gay (1991), descriptive method is considered appropiate to describe the present condition of research subject. Arikunto (2002) also stated the descriptive research as a research that explains or describe the present condition. Based on the opinions, the researcher design this research as descriptive research. The data of this study was analyzed by using both qualitative and quantitative method (mix method).

Descriptive qualitative method was used since the researcher needed to describe the result of the data. Meanwhile, quantitative method was used since the researcher needed to calculate the data to get percentage before describing it. Keegan (2009:11) stated that qualitative research is less easy to define. It explores question such as what, why, and how many. It is concerned with meaning than measuring. Next, Arikunto (in Perdasari, 2008:21) stated that descriptive research does not test the hypothesis but only describes what was being seen, faced, observed and known.

The object of this research were transcript of monologue by Jim Jefferies, Ricky Gervais and Bill Burr stand-up comedy performances. The duration of each stand-up comedy perfromance videos about approximately 7 minutes. The object of this research consisted of ten videos transcript of Jim Jefferies, Ricky Gervais, and Bill Burr stand-up comedy performances.

The instruments which were observation checklists. The sheet would analyse the narrative feature and stand-up comedy techniques of each stand-up comedy performance by Jim Jefferies, Ricky Gervais, and Bill Burr. Observation checklist became guidance to analyze the data, and then observation checklist gave to co-rater in order to gain inter-rater aggrement. This instruments analysed two element, first is the narrative section based on Labov's model, second is the stand-up comedy techniques used by comic. The observation checklist for the co-rater helped the researcher proved the data analysis was correct or not.

There were several steps in order to do this research. First, watching the videos of monologue by Jim Jefferies, Ricky Gervais, and Bill Burr stand-up comedy performance. Second, the videos would be transcripted, therefore the data could be analyzed. Third, identifying the narrative section in the monologue of Jim Jefferies, Ricky Gervais, and Bill Burr by using Labov's model. Fourth, identifiying the technique used by those comics. Fifth, identifying the common pattern that used by all of them. Sixth in order to check the reliability of the data analysis, the co-rater would analyse sample of the monologue ot its narrative section and rhetorical techniques. Seventh, the result 
would be compared with those of investigator. Inter-rater aggreement would be calculated, and then the data would be calculated. Finally the data would be displayed in table or figure.

According to Moleong (2001:125), data analysis is a process of organizing and clasifying data into a certain pattern, category, and basic unit of analysis so that the theme can be found. First of all, the researcher would transcript all stand-up comedy performance by three of them. After that, reading the trancript and uderstanding the transcript. The researcher created checklist which consisted of the narrative analysis section and stand-up comedy techniques. After that, the researcher analysed the stand-up comedy techniques used in every part of narrative section. Collecting the possible narrative sections and stand-up comedy techniques found in all stand-up comedy transcript. The researcher choosed one co-researcher in order to helped researcher to conduct the research by analyse the sample of the research. In order to choosed the sample, the researcher would do random sampling before given to the co researcher.

The researcher will give two weeks in order to analyse the sample. The coresearcher also analysed the narrative section of comics and techniques. When there was disagreement between the researcher and co-researcher in coding possible narrative sections and stand-up comedy techniques found in Jim Jefferies, Bill Burr, and Ricky Gervais performances, it would discuss it to find out the reason for the difference and to produce a better result. Last, the researcher drew conclusion and suggestion based on the data analysis.

To ensure the validity and reliability of the analysis, the researcher would use validity and reliability, by choosing a coresearcher to validate the data which have been found and an inter-rater reliability index of 0.81 (Карpa) such as used in the previous study by Hyland (2004). Cohen's kappa is a statistic which measures interrater agreement for qualitative (categorical) items. This inter-rater reliability will give score of how much homogeneity or consensus between corpus.

The process of ensuring the reliability using Cohen's Kappa will be using SPPS, however, the basic formula of Cohen's Kappa is shown as below:

$$
K=\frac{P o-P e}{1-P e}
$$

Description:

$\mathrm{K}=$ Cohen's Kappa coefficient

Po = Proportion of observed agreement

$\mathrm{Pe}=$ Proportion of expected agreement

1 = Constanta

The result of Kappa can be interpreted as follows :

Table 1. Scale of aggreement of Cohen's

\section{Kappa}

\begin{tabular}{|l|l|}
\hline$\leq 0$ & Indicating no agreement \\
\hline $0.01-0.20$ & None to slight \\
\hline $0.21-0.40$ & Fair \\
\hline $0.41-0.60$ & Moderate \\
\hline $0.61-0.80$ & Substantial \\
\hline $0.81-1.00$ & Almost perfect agreement \\
\hline
\end{tabular}

This interpretation allows for very little agreement aong raters to be described as "substantial". For percent agreement, 61\% agreement can immediately be seen as problematic. Almost $40 \%$ of the data in the dataset represent faulty data. This could lead to recommendations for changing practice based on faulty evidence. The recommended agreement is $80 \%$ as the minimum acceptable interrater agreement. Accepting $0.40-0.60$ as "moderate" may imply the lowest value (0.40) is adequate agreement. Kappa values below zero, although unlikely to occur in research data, when this outcome does occur it is an indicator of a serious problem. A negative kappa represents agreement worse than expected, or disagreement. Low negative values $(0$ to 
-0.10) may generally be interpreted as "no agreement". A large negative kappa represents great disagreement among raters. Data collected under conditions of such disagreement among raters are not meaningful.

\section{RESULT AND DISCUSSION \\ Result}

In order to analyse the verbal language

that told by those comics, the researcher transcript their performances in every topic of story. Total utterances from those comics are 3.475 utterances.

The result of validity and reliability with co-researcher using Cohen Kappa showed, the reliability stand-up comedy techniques in narrative sections (Labov's Model) used by Jim Jefferies, Bill Burr, and Ricky Gervais is good. After being calculated by Cohen Kappa system, it is showed that the data between researcher (rater 1 ) and co-researcher (rater 2) have $85 \%$ of agremeent and 0,868 Kappa. According to Fleiss (1981), equally arbitrary guideliness which characterize kappas over 0.85 is excellent reliability. Meanwhile, the validity of the data is good.

The Narrative Section (Labov's Model) used by Comics

Research question number 1 asked about the sections of narrative are frequently found in narrative monologue by Jim Jefferies, Bill Burr, and Ricky Gervais in their stand-up comedy performances that each of them performed in 5 different topic of comedy.

Table 2. Narrative Sections of Comedy

\begin{tabular}{|c|c|c|c|c|c|}
\hline \multirow[b]{2}{*}{$\begin{array}{l}\text { Narrative } \\
\text { Sections }\end{array}$} & \multicolumn{3}{|c|}{ Name of The Comic } & \multirow[b]{2}{*}{$\begin{array}{l}\text { Tota } \\
\text { I }\end{array}$} & \multirow[b]{2}{*}{$\begin{array}{l}\text { Percen } \\
\text { tage }\end{array}$} \\
\hline & $\begin{array}{l}\text { Jim } \\
\text { Jeffer } \\
\text { ies }\end{array}$ & $\begin{array}{l}\text { Bill } \\
\text { Bur } \\
r\end{array}$ & $\begin{array}{l}\text { Ricky } \\
\text { Gerv } \\
\text { ais }\end{array}$ & & \\
\hline Abstract & 9 & 10 & 13 & 32 & $100 \%$ \\
\hline Orientation & 9 & 10 & 13 & 32 & $100 \%$ \\
\hline $\begin{array}{c}\text { Complicating } \\
\text { Action }\end{array}$ & 9 & 10 & 13 & 32 & $100 \%$ \\
\hline Resolution & 9 & 10 & 13 & 32 & $100 \%$ \\
\hline Coda & 8 & 8 & 11 & 27 & $84,37 \%$ \\
\hline
\end{tabular}

Table shows that abstract, orientation, complicating action, and resolution are found in all comic with frequency of 32 times or $100 \%$. There is a difference with coda part in narrative section. Coda part has the lowest frequency rathen than any part of narrative with frequency is 27 times or $84,37 \%$. In their performances, comics have different frequency in using narrative sections this thing happen because on some topics, comics told more than one stories in one topic. These are the example of narrative section based on Labov's model.

Example 1 Now...l got my girlfriend pregnant after knowing her for six weeks. I feel... Yeah, no, it's not good, six weeks. I think she wants to get married, and the reason I think that is 'cause she says that a lot. HHHH (Audiences' laughter) And I don't want to get married. (JJ2)

The above example is an abstract section found in JJ2 (Jefferies, topic 2) talking about Jefferies' girlfriend and concent about marriage. He put his girlfriend as object of the story and potray it to the audience which marriage is not a compulsory matter in America. He said that in the last utterance "cause she says that a lot", and the audience laugh with the joke. That means, he does not want to marry his girlfriend because he meet her just for six weeks.

Abstract is the beginning of the story. It is summary of the whole story with one or several clauses at the very beginning of the narrative. It also provide signals to mark the transition of the narrative. In this part, the comic was trying to build up the background of the story, and also as transition to move from another topic of stand-up comedy.

Example 2 Everyone in my life is pressuring me into getting married. I hate when my mother rings me up and goes, "Why don't you marry the 
girl? You have a child with her." And I'm like, "Yeah, I've got a kid. An 18-year commitment. I've signed onto that like a bad fucking phone contract." I'm a great dad. I got 15 years left, then I'm fucking off. Hhhh (Audiences' laughter) But marriage is until death. It's a shit contract. $\mathrm{HHHH}$ (Audiences' laughter) Hundred years ago, the life expectancy of an American was 52. Now it's 83. Fuck that! HHHH (Audiences' laughter). I've got a life to live! If I was gonna die at 52 , sure, let's have some company. hhhh (Audiences' laughter) (JJ2)

Example two is orientation part of the narrative sections in stand-up comedy. In orientation part, it can find the information of the story. It could about time, place, persons involved, and situations in the story. In this part, comic giving the information about the characters and the situation on the story. The characters that told by comedians are kid, girlfriend and people who pressure him to get married with his girlfriend. The comedians also provide situations, that his life will be in suffered condition when he got a kid in his life.

Example two tells about he is not ready to have a marriage life even if he has a child from his girlfriend, because when he marries his girlfriend, it means he needs to take care the kid for eighteen silly contract that probably put him in bad situation. He said that he is not a good father for his kids. Also he said marriage until death is worse contract, because he should live his wife for his entirely life even if he does not love his wife anymore.

Example 3 I would have got married in the Dark Ages, when $50 \%$ of women died during childbirth. I would have rolled the dice on that bad boy. Hhhh (Audiences' laughter).
But she works out every day and she eats kale just to spite me. $\mathrm{HHHH}$ (Audiences' laughter). Six weeks, she got pregnant. Six weeks! I feel like I missed out on something. Six weeks is very quick to get pregnant. I missed out on the new girlfriend. The new girlfriend's the best time of your life. That first three months of the new boyfriend or girlfriend, the new relationship, where the person's fucking perfect. And you're like, "Oh, my God... I love this person." After a month, you're like, "This..." You're drinking with her like, "She's drinking beer. Do you wanna watch <i>Star Wars?"</i> And she's like, "I do." And you're like, "Fucking hell!" HHHH (Audiences' laughter) Yeah, and she's getting along with your friends. Your mother's like, "I think she's the one." You go, "I think she's the one as well." hhhh (Audiences' laughter) 'Cause women can hold the psycho down for three months. HHHH (Audiences' laughter). For three months, they can walk around like a functioning member of society. Showing up at your work parties and not crying. Hhhh (Audiences' laughter). At three months and one day, you come out of the shower, and she's huddled over your phone like Gollum. Just... HHHH (Audiences' laughter). So I went from the new girlfriend, best feeling in the world, to dating a pregnant chick. Now, no one has ever said this and never recorded anything like this. No one's ever said it in a public forum, but the pregnant are the worst people on Earth. $\mathrm{HHHH}$ 
(Audiences' laughter) For some reason, society has told us that they have some type of glow or some shit. The pregnant are a bunch of cunts, the pregnant. HHHH (Audiences' laughter). They... They cry when they're happy, when they're sad. You don't know what fucking cry... And you ever tried fighting with a pregnant person in a public place? Hhhh (Audiences' laughter). Doesn't matter how right you are? HHHH (Audiences' laughter) $\mathrm{Me}$ and Kate, she was seven months pregnant, were walking around the supermarket, right? Walking around... and I got some Coco Pops to put in the trolley. Now, you call them Cocoa Krispies in this country. How different our cultures are hhhh (Audiences' laughter) And... I put the Coco Pops in the shopping cart. "Trolley." And, uh...And Kate picked them up and put them back on the shelf. It was very confusing 'cause I'd never seen Coco Pops go in the opposite direction hhhh (Audiences' laughter) And my brain skipped a bit, and I went, "Uh..." "I think you made a mistake there, Kate." And I went to get them back, and she goes, "You're not having them." And I went, "But I... I always have them." And she went, "You're getting fat." $\mathrm{HHHH}$ (Audiences' laughter) So I did my drop-themic moment. I picked up the Coco Pops and went... And she snapped and went, "Do you want me to lose this baby?" And I went, "Um, fuck, that was quick! Of course I do. You're a fucking nightmare!" HHHH (Audiences' laughter) (JJ2)
The above example is a complicating actions in narrative of stand-upcomedy. Complicating actions provide the informations about what happened. It can be called as the core of the story. Complicating action is longer than any other of narrative sections, because it contains all of the information of the story. It contains chronological order, provide the referential function of the narrative, reporting, 'a next event' in response to the potential question. Smith (2006) also steted that complicating action provides the backbone of the story and are the most reportable event. If there is no complicating action, there will be a narrative.

In the example three, the comic was telling the story that relating to the characters that already told in the orientation part. On that example, the complicating actions is talking about woman has potentially died during childbirth. It means he should rise his bad children by himself. Then he move to another kind of joke. He said his girlfriend only act as a good person for three months, after three month he would take everything in his life. He potrayed the situation which commonly happen in relationship. The worst thing is when his girlfriend get pregnant and he can not againts him in any kin situation. Because people would say that he is crazy when he try to offend pregnant woman in front of public.

Example 4 You ever been in a bar at 4:00 a.m., talking to some guy, and he's telling you how shitty his life is? And he's like, "My dad, my dad's an asshole. Didn't even know my dad. Walked out on my mum when she was pregnant with me." And I used to think, "What a dick." And now I'm like... "I'm sure he had his reasons $\mathrm{HHHH}$ (Audiences' laughter). Who am I to judge, eh?" (JJ2) 
The above example is a resolution part in narrative of stand-up comedy. On the resolution part, comedian should explain how the story will end. Resolution should contain how complicating action was resolved and resulted is expressed in this part. On that point, a resolution part should contain in every narrative, because it contains how the story resolved.

Example four talks about Jefferies who give up with his girlfriend and hear the someone's story at the bar that talk about how worse his father. The funny thing of this section is the person does not even know his father, because he left him when the mother pregnant with him. That is what the comic would do through his girlfriend.

\section{Example 5 So she gets pregnant. We got to} go to these baby classes. We go to baby classes at the hospital, where they teach you how to put nappies on and shit. And you swaddle. You've got the dummy, and you swaddle it. And then the lady goes, "That's a good swaddle." And you go, "I thought it was. I've been practicing."hhhh (Audiences' laughter) (JJ2)

The above example is a coda in narrative of stand-up comedy. In Labov's model, coda is the last part of narrative section. Coda is functional device for returning the verbal perspective to the present moment. Coda as closing of the story by bridging narrative content and the present. In the example 5, the comic tells about he is in baby classes at hospital with his girlfriend. The class taught about how to take care a baby.

\section{The Implementation of Stand-up Comedy Techniques used by Comics}

Research question number 2 asked about the common techniques used by all comics in every part of narrative section. Basically, the researcher concerns in the verbal language that trigger audience laughter. In this research the researcher classified stand up comedy techniques into 8 part, they are rule of three, one liner, impersonation, roasting, comparison, simile, observation, and callback

Table 3. Stand-up Comedy Techniques used in Narrative

\begin{tabular}{|l|c|c|c|c|}
\hline \multirow{2}{*}{ Technique } & \multicolumn{2}{|l|}{ Name of Comic } & \multicolumn{2}{l|}{$\begin{array}{l}\text { Tot } \\
\text { al }\end{array}$} \\
\cline { 2 - 5 } & $\begin{array}{l}\text { Jim } \\
\text { Jefferies } \\
\text { (Comic 1) }\end{array}$ & $\begin{array}{l}\text { Bill } \\
\text { Burr } \\
\text { (Comi } \\
\text { c 2) }\end{array}$ & $\begin{array}{l}\text { Ricky } \\
\text { Gervais } \\
\text { (Comic } \\
3 \text { ) }\end{array}$ & \\
\hline Rule of Three & 8 & 10 & 13 & 31 \\
\hline One Liner & 9 & 10 & 12 & 31 \\
\hline Impersonation & 0 & 1 & 6 & 7 \\
\hline Roasting & 3 & 4 & 1 & 8 \\
\hline Comparison & 3 & 5 & 1 & 9 \\
\hline Simile & 1 & 2 & 6 & 9 \\
\hline Observation & 3 & 6 & 5 & 14 \\
\hline Callback & 3 & 2 & 0 & 5 \\
\hline
\end{tabular}

The researcher count the techniques were implemented when those jokes successfully trigger audience laughter. There are techniques used in every narrative section by all of three comics.

Table 3 showed that one liner and rule of three techniques are the most techniques used by comics with frequency is 31 times in every story. Also, observation technique is used by comics in total frequency is 14 times. Observation technique is third highest technique that used by three of them. Comic 1 only used observation technique in 3 times of his whole stories. The second comic is the comedian who use more observation techniques than any others with 6 times in all story. Callback technique is the less technique that used by all comic.

Table 3 also shows that there are two comic who do not use one particular technique. Comic 1 do not use impersonation technique in his performance, he never use it in every narrative. Also comic 3 do not use callback technique in his performance in order to trigger audience laughter.

These are all of the examples of stand-up comedy techniques that implemented by all comics in their performances. These are the 
examples of the stand-up comedy techniques that used by three of them, as stated below :

Rule of three is the most frequent technique used by all of three comics in order to tigger audience laughter in every story of narrative. There are several examples from each comic, as stated in example below :

Example 6 Don't Shake the Baby is 40 minutes long. You don't need to watch Don't Shake the Baby. All the information you need is in the title. $\mathrm{HHHH}$ (Audiences' laughter) (JJ 2)

You talk about life, right? "What's that, son? Uh, we're not going to church today. HHHH (Audiences' laughter) (BB 3)

Example six is the rule of three technique used by all of three comics. Rule of three contain of three utterances to trigger audience laughter. On this technique, the comics should make the last utterances as the funny part of the joke. In example six, the last utterances are the punchline of the joke. On JJ 2, the punchline means the comedian does not need to watch the whole video in order to get the meaning of video. BB 3 is talking about people activity that usually go with their son to go to church, the punchline when he potray the contradict activity that he will not go to church with his son. In America, parents often take their children to the church in order to make the children be religious person. The contradictive is potrayed in BB3, where he does not want go to church and say it to his child.

These are several example of one liner technique in stand-up comedy performances as stated in example 7 below :

Example 7 Anytime anything broke in the house, five minutes into fixing it, he was bitching about his marriage. HHHH (Audiences' laughter) (BB 3)

Jesus killed your puppy on his birthday 'cause you didn't spend enough on your uncle's Christmas present." $\mathrm{HHHH}$ (Audiences' laughter) (RG 3)

One liner is a simple technique that comic currently use in every performance. On the example seven of BB3, the comic use the word "bitching" which means insulted the marriage. On the example of RG3, the comic put God as his object of the joke. He said "Jesus killed your puppy", it means that god killed the puppy and that is god's plan by killing the puppy.

Since impersonation technique only used by two comics, there will be less example of this technique.

Example 8 My girlfriend doesn't like it 'cause she says I have a temper, you know? She's like, "You know, it's just not that you're trying to fix things, it's that you get frustrated, you punch the wall, the dog starts shaking. I just don't think it's a good idea. You know, you're a comedian. You should tell jokes. "He's a plumber. He should plumb, right?" (BB 3)

They call him up, do they? Ring ring. Ring ring. "Yello?" "Uh, can I speak to God, please?" "Speaking." "Oh, I didn't think you'd answer the phone yourself." "What do you want?" hhhh (Audiences' laughter) "Oh, um, that volcanic ash cloud... Was that you?" "Yeah yeah. Hhhh (Audiences' laughter) Yes, that was an act of me, all right." "So I shouldn't pay out?" "No, don't fucking pay 'em a penny, son, no." $\mathrm{HHHH}$ (Audiences' laughter) "Brilliant brilliant. While I've got you here, did you make a tree fall on Steve Baxter's car?" "There's a lot of Steve Baxters." 
"Steve Baxter, 2 Acacia Road, Hounslow. It happened at 2:15 on the 3rd of June this year." "2:15, 3rd of... No, that wasn't me. I was in Africa that day giving AIDS to babies." $\mathrm{HHHH}$ (Audiences' laughter) (RG 1)

From those examples, comics had successfully imitate or creating a persona that they wanted. On first part of the example eight, the comedian imitate his girlfriend by acting or speaking like his girl. Also he change the voice in order to fit in with the persona. On the second part example eight, the comedian was acting like he had a conversation with god, and also he was acting he is a god. He potrayed the god who is almighty and can do anything to his creature. The funny thing is when the comic said "I was in Africa that day giving AIDS to babies", which means there are a lot of case about babies who infected by AIDS and all those things happen because of God's desire.

Roasting technique is technique that put person or group of people as an object of the jokes. It means the comics made someone or group of people into their joke. Comic 2 has used this technique for 4 times, and comic 3 only used this technique one times in his whole performances. These are the examples of roasting technique as stated in example 9.

Example 9 Bill Cosby. Now, I don't know if you get all the news here in Nashville...but I may say something that's very upsetting to many of you. It turns out that Bill Cosby is a rapist. $\mathrm{HHHH}$ (Audiences' laughter)(JJ 1)

Who do they think they're fooling with their stupid... You know? And then you lie to yourself: "I'm just gonna do a little...just gonna do this.Just gonna have this done." No, you're not. You're not. What, are you just gonna wax the Fender on your car then that's it, and the rest of it looks all shitty? "Well, maybe I'll just do the hood. And maybe I'll do the back." That's how it happens. Then you look like one of those real housewives... Face all twisted up. Fucking idiots. Hhhh (Audiences' laughter) "Hey, do I look... "yeah, they're idiots! "Do I look like I'm in my 20s?" No, you look weird. $\mathrm{HHHH}$ (Audiences' laughter) You look fucking weird. You still look likeyou're in your 50s. I just can't guess what year anymore because I've never seen that year. I've never seen that shiny fucking look. It's almost like you discovered a new age between 52 and 53. HHHH (Audiences' laughter) (BB 2)

In example nine at JJ 1 , comedian puts Bill Cosby as his object of the joke. He made a joke that relating to Bill Cosby and it was successfully trigger audiences laughter. It dealing with the fact Bill Cosby is rapist who rape more than 50 women. The ironic thing is Bill Cosby known as good person who would not do such kind of raping someone. The comic put him as central of the joke, and put it as a punchline of the joke. In other hand at BB 2, comedian tried to put women who do plastic surgery as an object of joke. He told that women who are in 50 years old and tried to look younger is a silly thing. Plastic surgery is silly thing for old people, the comic said that "Hey, do I look... "yeah, they're idiots! "Do I look like I'm in my 20s?" No, you look weird."

Comparison is technique that comic try to compare one thing to another. The punchline of the joke is in the differenciation between thing that differenciated by comic. These are the example of comparison technique by comics as stated in example ten 
Example 10 Now, the gun control routine has been shown in most news outlets. It was shown in the $<\mathrm{i}>$ New Yorker $<$ i $>$ as an article. It was shown in the $<\mathrm{i}>$ Washington Post $</ \mathrm{i}>$ as an article. It was shown on CNN as news, and it was shown on Fox for different reasons. $\mathrm{HHHH}$ (Audiences' laughter) (JJ 5)

No, but I mean...But we've gotta do something. We've gotta intervene. And people say, "No, it has nothing to do with you. It's up to them. It's their body. It's their life." And that's true, but we don't say that about wearing crash helmets. Or if you've got a heroin addict in the family, you don't go, "Oh, it's his life. He loves heroin." $\mathrm{HHHH}$ (Audiences' laughter) (RG 2)

Example ten at JJ 5, the comedian tries to potray news outlet that show about gun control. At his last utterance, he potrays Fox news that basically contain sport news. At RG 2 , he let people who become as heroin addict.

Simile technique, the comic three (RG) has the highest frequency on using this technique. These are the examples of simile technique.

Example 11 So I was like, "What's wrong with getting a pistol?" He goes, "I'll tell you why,buddy. 'Cause life...Life ain't a movie. You feel me?"I'm like, "No,can you please stop speaking in these backwoods riddles? $\mathrm{HHHH}$ (Audiences' laughter) (BB 1) I mean, there's your first clue. When did that happen? When did fat people just give up? When did they go into a shop and go, "Oh, fuck it. Just treat me like a farmyard animal."
HHHH (Audiences' laughter)

This technique expose the exegerated and ironic forms of jokes. This is the main purpose of simile technique. In example eleven at BB1, he said that people who have gun at their home would have bigger chance to get shot. Also at RG 2, he potrayed the ironic joke tha fat people would like to treat as farmyard animal.

Move to another techniques, there are several examples used observation technique in stand-up comedy performance, as stated below:

Example 12 The new girlfriend's the best time of your life. That first three months of the new boyfriend or girlfriend, the new relationship, where the person's fucking perfect. And you're like, "Oh, my God... I love this person." After a month, you're like, "This..." You're drinking with her like, "She's drinking beer. Do you wanna watch <i>Star Wars?"</i> And she's like, "I do." And you're like, "Fucking hell!" HHHH (Audiences' laughter) Yeah, and she's getting along with your friends. Your mother's like, "I think she's the one." You go, "I think she's the one as well." Hhhh (Audiences' laughter) (JJ 2) Let somebody else go in there... Take the fucking beach.You lay back...Wait it out. They're just lying to people. "No, no, it looks great. Looks great. Put a little ice on it,we'll see youin a couple of weeks. All right, take it easy. Jesus Christ! What the fuck happened? Hhhh (Audiences' laughter) We followed every step. Did we miss something? Hhhh (Audiences' laughter) Oh, hey, hey, hey! Oh, here's your 
keys. Here's your keys.There you go, there you go. Almost didn't recognize you,you look so young. Hhhh (Audiences' laughter) All right, take it easy. She gone?All right, she's gone. Shred everything.Shred it!" No, you're nuts.You wait it out. (BB 2)

In observation technique, comics relating his personal life with jokes. On the first example, the comic put his personal life with his girlfriend and make this as a joke with attracted language. At JJ 2, the comedian create a joke when the new girlfriend is the best in his life, but it change when one motnh relationship. The example 22 at BB2, the comic expose the life of people who would try getting younger than their age or doing plastic surgery.

In callback technique, only two of three comedian who used callback technique in performing jokes. Callback means retelling the joke that already told before, and make this into new jokes that can trigger audience laughter. These are examples that used callback technique in order triggering audience laughter.

Example 13 Bill Cosby. Now, I don't know if you get all the news here in Nashville...but I may say something that's very upsetting to many of you. It turns out that Bill Cosby is a rapist. (Roasting) HHHH (Audiences' laughter) .........If you wanna know, my actual opinion is this. I don't wanna be raped by Bill Cosby. (Callback) HHHH (Audiences' laughet) He's a horrible fucking man and should go to prison. That's what my real opinion is.

The above example is the example of callback. The punchline of the previous joke has retold by comic in order to triggerring audience laughter. The punchline of the joke is Bill Cosby, and put it into another joke. Bill Cosby in this case become the strong punchline of the joke. The callback technique recognized when the comic made Bill Cosby as punchline again in his performance. He said that "If you wanna know, my actual opinion is this. I don't wanna be raped by Bill Cosby", it showed that when he said about he does not want to be raped by Bill Cosby, it can trigger audience laughter.

\section{Common Pattern of Stand-up Comedy used by Comics}

Research question number 3 asked about the common pattern used by all comics of narrative sections. In this case, there are two common pattern in narrative story of stand-up comedy performances based on the result of narrative section used by all of three comics.

Based on the two figures, there are two common pattern used by all of three comics. First is the complete form of narrative section based on Labov's model. Second is the incomplete form of narrative section based on Labov's model. On the figure 2, there is no coda section in comics narrative story.

They just move to another story when all of them finish part of resolution, but it is only happened in the same topic. When they have more than one story in one topic, it means the story is not really long. They left coda as a transition part in order to move to another story, but it is not happen when they would like to move to another topic of stand-up comedy. The criteria for justifying and classifying the frequencies are defined according to Kanoksilapatham (2005). If a particular part occurs in every topic of standup comedy (100\%), it is regarded as 'obligatory', if the occurrence of a narrative part is below $60 \%$, it is 'optional', and if the occurrence ranges from $60-99 \%$, the move will be classified as 'conventional'. So, abstract, orientatin, complicating action, and resolution categorized as obligatory and coda categorized as conventional. 


\section{Discussion}

The finding of this research is three of comics tend to use Labov's model in their performances, with five sections. They are abstract, orientation, complicating action, resolution, and coda. According to Labov (1972), a good narration should have 5 components in order to create a good one. Stand-up comedy performance is one of a kind narrative, that is why all of the comic should have a good sections of narrative. Also stated by Brodie (2014), stand-up comedy is kind of performance that need sets of technique and narrative histories. The narrative section also helps the comics in order to persuade the audience to follow the story that given by comics. Therefore, the narrative section is needed in stand-up comedy performances.

Labov's model can be implemented in stand-up comedy performance. All of three comics already used the narrative sections that suggested by Labov. This is probably because Labov's model is already used by the majority of famous comic in order to attract audience attention with their narrative story. They tend to use narrative section based on Labov's model properly.

The second finding is the most common technique used in all of comics on their performances. The result of this research, rule of three and one liner techniques are the most technique used in every story of three comics. These techniques are the most simplest technique that can implement in stand-up comedy performances. It is proven by both of techniques are frequently found in every story of three comics. Rule of three and one liner techniques are the most effective technique that can trigger audience laughter in each of stand-up comedy stories. According to Stark et al (2005) one liner jokes are humorous because they violate the initial expectations of the listener, and that this violation is resolved by shifting from the initial knowledge frame used to understand the joke to another completely different knowledge frame. Therefore, on applying one liner technique for creating one liner joke, the comic should be able violate what the listener expect from the utterance in order to trigger audience laughter.

Meanwhile according to Papana (2012), rule of three technique can create strong punchline of the joke. From rule of three technique, the strong punchline can be released to the surprise and absurdity contained in the third utterance. In rule of three technique, the comics violate the expectation of the audience to another framing of knowledge and make it as a punchline of joke. The previous study also found the similar findings, according to Muhammad (2017), rule of three and one liner techniques are strong techniques in order to triggering audience laughter on comic performances.

The third finding of this research is the most common pattern used by three comics of narrative sections. The researcher found that abstract, orientation, complicating actions, resolution of the narrative sections are exist in all 'of stand-up comedy perfomances. It means that these three comics used narrative model that suggested by Labov.

Meanwhile in some stories, three comics do not use coda on their narrative story. Coda in narrative section as a sign of story transition or the signal that one story has ended. In this case, when they do not use coda as the signal for changing the story, they use resolution part in order to move to another story. Based on the result, there are two kinds of pattern in narrative sections. First is complete narrative section which use all narrative section and the second is incomplete narrative section which does not use coda part in narrative section. The researcher assumed that part of coda will not change the narrative performed by all of three comic. It means whether or not coda part is exist in the story, it will not affect the audience laughter. This is also stated by Safnil 
(2010), coda in narrative story is only an additional thing or it can be categorized as a peripheral element. Therefore, three comics sometimes leave coda in their narrative story of stand-up comedy performance.

Based on the result of this research, narrative section and stand-up comedy techniques effect the comics' performance. They should make audiences interested with the performance by creating good narrative section, so the audience can follow the story given by comics. The comics is not about simply convincing an audience that they are funny, although that is neccessary; it is also teaching the audience that there is a different way to think about it. (Sankey, 1998). It means the stand-up comedy deliver their idea or critics toward people through comedy performance. The stand-up comedy techniques help the comics in order to make their idea or critics become funny. Therefore, the narrative section and stand-up comedy techniques are important in stand-up comedy performance.

The limitation of this research is only focusing on stand-up comedy techniques which can trigger audience laughter and also analyse the narrative section used by all of three comics in every performance. The researcher assumed all of three comic are successful to performing joke in front of their audiences, because all of them are well known comics. This research would not measure the quality of the jokes performed by all of three comics.

\section{CONCLUSION AND SUGGESTION Conclusion}

The research was aimed at finding the frequently section of narrative based on Labov's model, the most common technique used by three of comics in order to triggering audience laughter and common pattern used by three comics in narrative section.

The narrative section is already used by three comics in order to help them create the good narrative story that suggested by
Labov. The narrative section help the comics in order to persuade audience to follow the story, therefore the audiences can get the jokes that given by comics.

The second finding showed that there are two most common technique used by three comics. Stand-up comedy techniques help the comics in order to strengthen the jokes, rule of three and one liner are the most effective and simplest technique in order triggering audience laughter in every narrative section. Stand-up comedy techniques help the comics to deliver their ideas or critics on comedy performance in effective way and the audiences still count them as a joke.

The third finding of this research, the common pattern currently used by three comics on performing narrative story of stand-up comedy is Labov's model. Even if one of part narrative section is not used in comics' stand-up comedy performance, it still counts as narrative section that suggested by Labov, because the coda part is a peripheral element in narrative sections

On performing stand-up comedy, the comics is not only creating good narrative, but also they used the stand-up comedy techniques in order to strengthen the jokes.

\section{Suggestion}

English teacher should be familiar with narrative sections and stand-up comedy techniques if they want to use comedy in teaching and learning material. Teacher also can use stand-up comedy technique in order to delivering joke in classroom activity. Through comedy in teaching material, students could pay attention or attracted toward the material that given by the english teacher. Therefore, it can enhance the qualitiy of the teacher, because the students like the teacher who have sense of humor in classroom activity,

The future researchers who want to conduct the similar research or related to stand-up comedy. The future researchers are 
suggested to do research about the joke content in comics' stand-up comedy performance. So, the further reasearch could be analysed on audiences respond toward the stand-up comedy content, it could dealing with the culture of audiences or background of comics on how their develop the jokes in stand-up comedy performances.

\section{REFERENCES}

Arikunto, Suharsimi. 2002. Metodologi

Penelitian. PT. Rineka Cipta. Alexander,

Richard J. 1997. Aspects of verbal humour in English. Tübingen: Narr.

Attardo, Salvatore. 2001. Humorous Texts: A Semantic and Pragmatic Analysis. Berlin : Mouton de Gruyter.

Bitzer, Llyod F and Edwin Black. 1971. The Prospect of Rhetoric:Report of The National Development Project. Michigan University: Prentice-Hall

Brodie, Ian. 2014. A Vulgar Art : A New Approach to Stand-up Comedy. University Press of Missisipi.

Gay, L.R. $\quad 1987 . \quad$ Educational Research:Competencies for Analysis and Application. New York:Merril Pub.Co.

Gay, L.R. 1991. Educational Evaluation and Measurement:Competencies for Analysis and Application. New York: Macmillan Publishing Company.

Greenbaum, Andrea. 1999. Stand-up Comedy as Rhetorical Argument : An Investigation of Comic Culture. Humor. 12.1. 33-46

Hockett, Charles F. 1977. Jokes. The view from language, ed. by C. F. Hockett, 257-289. Athens, GA: University of Georgia Press.

Holmes, Janet. 1992. An Introduction to Sociolinguistics. London: Longman.

Ishara, Rodeka Enggar. 2016. An Analysis of Rhetorical Structures of The Grand Final of World Debating
Championship in 2009. Bengkulu: Universitas Bengkulu

Johnstone, Barbara and Christopher Eisenhart. 2008. Rhetoric in Detail. Philadelphia: John Benjamins Publishing Company

Kanoksilapatham, B. (2005). Rhetorical structure of biochemistry research articles. English for Specific Purposes, 24, 269-292. http://dx.doi.org/10.1016/j.esp.200 4.08.003

Kaya, Emel Kokpinar. 2014. An Analysis of Conversational Narratives in Turkish. Ankara : Hecettepe University

Keegan, Sheila. 2009. Qualitative Research:Good Decision Making Through Understanding People, Cultures and Markets. Pennsylvania State University:Kogan Page

Labov, W. (1972). Language in the inner city. Philadelphia: University of Pennsylvania Press.

McHugh, Mary L. 2012. Inter-rater Reliability : The Kappa Statistic.

Michael, McCarthy. 2000. Discourse Analysis for Language Teachers. Cambridge: Cambridge University Press

Mintz, Lawrence E. 1983. Humor and Popular Culture. Handbook of Humor Research. Vol. II, ed. by Paul E. McGhee; and Jeffrey H. Goldstein, 129 - 142. Mew York : Springer

Misje, Anne-Karin.2002. Stand-up Comedy as Negotiation and Subersion. "In Popular Imagination: Essays on Fantasy and Cultural Practice. Finland : Nordic Network of Folklore Moleong, Lexy J. 2001.Metodologi Penelitian Kualitatif.Bandung: Remaja

Muhammad, Oki. 2017.Gaya Kominikasi Comic Komunitas Stand Up INDO PKU Pekanbaru. Universitas Riau.

Nilsen, Allen Pace. 2000. Living Language. Boston,MA : Allyn and Bacon. 
Papana, Ramon. 2016. Buku Besar Stand-up Comedy Indonesia. Jakarta : PT Elex Media Komputindo.

Rutter, Jason. 2001. Stand-up Interaction:Performance and Audience on Comedy Venues. University of Salford

Sankey, Jay. 1998. Zen and Art of Stand-Up Comedy. London : Taylor and Francis Ltd

Safnil. 2010. Pengantar Analisis Retorika Teks. Bengkulu : FKIP UNIB Press

Scwarz, Jeannine.2010. Linguistic Aspects of Verbal Humor in Stand-up Comedy. Saarland : Saarland University

Smith, J. 2006. Narative : Sociolinguistic Research. York : Elsevier

Smith, Melinda. 2013. Laughter is the Best Medicine:The Health Benefits of Humor and Laughter". Retrieved on January 3. 2018 from http://m.helpguide.org/articles/ emotional-health/humor-laughterhealth

Stark, Jeff. Kim Binsted and Ben Bergen. 2005. Disjunctor Selection for OneLine Joke. Hawai : Univeristy of Hawaii

Veale, T. 2013. Humorous similes. Humor, 26(1), pp. 3-22. Retrieved 29 April. 2018, from doi:10.1515/humor2013-0002

Ziv, Avner. 1986. Jewish Humor. Tel Aviv:Papyrus 